Retail Innovation and Shopping Practices: Consumers' Reactions to Self-Service Retailing.

This is an author copy of a paper published in Environment and Planning A, Vol. 40, Number 9, 2204-2221 (2008). As such its format may differ from the final version published in the journal. Tables are provided at the end of the paper.

Andrew Alexander*, Simon Phillips* and Gareth Shaw ${ }^{+}$

Address for correspondence

*School of Management

University of Surrey

Guildford

Surrey

UK

GU2 7XH

Contact Author: Dr Andrew Alexander (A.Alexander@surrey.ac.uk)

${ }^{+}$School of Business and Economics

University of Exeter

UK 


\begin{abstract}
$\underline{\text { Abstract }}$
In this paper we address the related issues of retail innovation, changing shopping practices and shopping geographies. We do so in relation to the spread of self-service grocery stores, and particularly the supermarket, in the post-war retail environment of Britain (1950-1970), arguing that this juncture provides a propitious opportunity to study the relationship between changing practices of retailing and consumption. We highlight shoppers' selective adoption of new self-service formats in relation to certain product categories and argue that this can be explained in part by reference to the socially embedded nature of women food shoppers' behaviours and in particular the influence of contemporary notions of the 'good housewife'. We support our argument by reference to a wide range of contemporary documentary material relating to post-war shopping including market research reports, the publications of local consumer groups and selected retailer and government archive sources.
\end{abstract}




\section{Retail Innovation and Shopping Practices: Consumers' Reactions to Self-Service Retailing.}

\section{Introduction}

In his paper exploring the development and implications of self-service retailing in Britain, du Gay (2004: 151) contends that “...the growth of self-service was a more uneven and contingent affair than many of the industry accounts and critical commentaries upon them suggest." This paper considers in more detail the extent and implications of any such unevenness and contingency resulting from consumers' reactions to self-service grocery shopping and its apotheosis in early postwar Britain - shopping in the supermarket. In doing so it highlights an insufficiently considered aspect of consumers' uneven usage of self-service stores and supermarkets in geographies of retailing and shopping in post-war Britain, viz. unwillingness to purchase the increasingly wide range of products and services being offered in such stores.

An explanation for this so-called "selective adoption" behaviour (Goldman, 1982 ) is derived primarily through an engagement with literature seeking to refine the conceptualisation of the meanings that underpin shopping practices (see particularly Miller, 1995; 1998; Miller et al., 1998; Gregson et al., 2002; de Grazia, 2005; Jackson et al., 2006). In addition, a connection is made between such debates and the notion of perceived risk in shopping and consumption as developed in the marketing literature (Mitchell, 1999; Cases, 2002).

A number of cultural histories of consumption have significantly increased our broad understanding of the impacts of the supermarket (see for instance Humphery, 1998; Bowlby, 2000; de Grazia, 2005). This paper looks in detail at a specific aspect 
of the reaction of consumers to the changing shopping environments of post-war Britain by analysing their reported attitudes and behaviours toward the purchase of fresh meat and greengrocery from self-service grocery stores and supermarkets. Exploration of these very specific shopping activities, we argue, provides further evidence of the social embeddedness of shopping in relation to the link between consumption and identity (Miller et al., 1998; Jackson, 1999) and to the constitutive role of shopping geographies in the formation of shopping space (Gregson et al., 2002: 615; see also Jackson et al., 2006). As such, the paper augments a wider body of work on retail change and shopping practices forming part of what has been termed the new retail geography (see Wrigley and Lowe, 1996; Wrigley and Lowe, 2002).

Throughout the paper we focus almost exclusively on the reported attitudes and behaviours of women shopping for food for the family or household. In doing so we are mindful of the dominant role of women in performing such tasks. Nonetheless we acknowledge the influence of husbands on the shopping process (Joyce, 1967; Lury, 1996; Thompson, 1996) and that women's food shopping was subject to validation by family, friends, and society more widely (see de Grazia, 2005: 409).

\section{Retail change and shopping practices}

Insufficient attention has been given to explorations of unevenness in food shoppers' reactions to the new self-service environments, although the propensity for disaffection, anxiety and contestation, and their implications, were recognised from the outset (see for example Humphery, 1998; Alexander et al, 2005; Phillips et al., 2005). Goldman's exploration of consumers' selective adoption of the supermarket in developing economies provides a useful starting framework. In this work he highlights the distinctions between geographic, economic segment and product 
category diffusion of the new format (Goldman et al, 2002; see also Goldman, 1982; 2001). Goldman (1982) identifies both 'dual' and 'joint' food retailing systems. Dual systems emerge in situations where one group of consumers continues to use traditional providers whilst another group uses alternative, new format providers. Joint systems emerge in cases where the two systems are jointly utilised and shared by all. We utilise these notions in following sections of the paper in revealing that some consumers did indeed exhibit a tendency toward the selective adoption of the products offered by self-service grocery retailers, and particularly the supermarket. We then briefly consider some of the attempts by retailers and producers to alter this behaviour.

Some explanation for the trend of selective adoption and resulting shopping practices and geographies we identify can be drawn from work that seeks to reveal how consumption can help constitute identity, where identity is articulated in relational terms, influenced by, amongst others, notions of the family and associated expectations about gender (Jackson, 1999:25). The work of Miller (1998; Miller et al, 1998) is particularly important in this regard. Informed by an ethnographic study of shopping attitudes and behaviours, Miller develops a theoretical argument that reveals the need for shopping to be understood in terms of the dynamics of social relations (Miller, 1998; see also Zukin, 2004).

The role of social relations can be seen clearly in women's food shopping for the family, in which a woman tries to meet "... a series of responsibilities and concerns with which she strongly identifies and of which she is generally proud" (Miller, 1998: 17; see also Strasser, 1982; Thompson, 1996). The ways in which women negotiated with these responsibilities and concerns differed by social class, but such responsibilities were not diminished by the increasing role of many women 
in the paid labour market (Lewis, 1992). Nor were they lessened by the innovation of self-service as a means to streamline food shopping, with shopping itself becoming an increasingly important aspect of housework as more dependence became placed on goods provided by the market (Lury, 1996: 126; Bowlby, 1984). As Usherwood (2000: 128) notes in her study of food shopping and the supermarket "the traditional nurturing role of women was not challenged but was recast for modern times." Bowlby (1994) reveals some of the implications of this recasting in her illustration of the inter-relation between spheres of work and home in women's lives by reference to food shopping during the 1960s, with its increasing emphasis on convenient shopping environments and food products for the busy working woman.

Furthermore, the heightened legitimacy of housework during and immediately following the Second World War combined with it being increasingly positioned as “...an expression of love and warmth performed by each woman for her own family" (Lury, 1996: 127; Giles, 2005). Fox's analysis of household goods advertisements in a US women's magazine reveals an increased emphasis on the "labour of love" message during the twentieth century, a message which, among other themes attempts to "...raise the status of the work by implicating housework in the woman's most intimate relationships" (Fox, 1990: 34). This, she argues, provides insight into housewives' consciousness of their situation and responsibilities, as well as the attempts of advertisers to shape them ${ }^{1}$.

It is in light of these responsibilities that the notion of risk as developed in the marketing literature, and particularly that concerned with consumers' perceived risk in retail format selection, is informative here. Various dimensions of perceived risk have been identified, with psychological and social risk being among the principal

\footnotetext{
${ }^{1}$ The term housewife was widely used in the contemporary documentation on shopping habits of women during our study period. Our use of the term reflects this and carries no pejorative connotations.
} 
ones (Mitchell and McGoldrick, 1996; Mitchell, 1999; Cases, 2002). The salience of discussions of perceived risk comes in a number of ways, but most clearly in relation to the evidence from surveys undertaken during our study period revealing that housewives considered shopping for food and the provision of family meals as key tasks (see for example IPC, 1970; Bowlby, 1984). Hence, notions of psychological and social risk are more relevant to the process of food shopping than commonly portrayed; psychological risk reflecting the potential for women to be disappointed with themselves as a result of unsatisfactory provisioning of food for the family, and social risk reflecting the possibility for disappointment and disapproval among family, friends and society more widely. The perception of risk could be heightened further in the case of shopping for comparatively less branded, perishable goods such as fresh meat and fruit and vegetables (see Beharrell and Denison, 1995).

Debates on the social embeddedness of shopping practices have been extended in another direction by the work of geographers. In their paper on "shopping, space and practice" Gregson et al, 2002 (p615), note that the meanings of shopping, “...are produced in and through practice, through modes of shopping that bring together goods, looking, socialities and the rhythms of everyday life, as well as through the purchase." Clarke et al. (2006) and Jackson et al, (2006), explore this theme in two papers emanating from a detailed study of the long-term impact of retail restructuring on consumer choice at the local level. Looking at the implications of such restructuring at the household level, Jackson et al (2006: 61) highlight how household context mediates consumer choice within and between stores noting that "the socially embedded nature of people's shopping practices, rooted within the complexities of contemporary households and domestic routines, results in the development of a repertoire of stores in order to fulfil consumers' various needs." 
We consider that the study of food shopping behaviours in early post-war Britain can contribute to this debate also. Our study occurs at an important juncture at which some shoppers had the choice of whether to purchase goods by counter-service or self-service means. In this context, important questions include how and to what extent these choices, and the wider tapestry of food shopping geographies of post-war Britain, were mediated by changing household and wider social contexts as well as those of the changing retail landscape (Gregson et al, 2002).

Retailers, producers and store designers became keenly aware of the need to adapt elements of the American retail innovation of the supermarket to fit very different European markets (de Grazia, 2005). Discussions in the contemporary British trade press highlighted variations in economic conditions, land market and competition practices and consumer behaviour among others (Alexander et al., 2005). Adaptations were perhaps most necessary to reflect variations in food shopping practices. As de Grazia notes in her study of the supermarket in Europe, “...people's ways of provisioning are deeply embedded in all kinds of institutions, values, and beliefs, and these could pose formidable obstacles to this particular innovation." (de Grazia, 2005: 385; see also Spiekermann, 2006).

In sum, our reading of a wide range of literatures on post-war shopping and the housewife leads us to expect a complexity in women food shoppers' reactions toward the purchase of fresh meat and greengrocery from self-service grocery retailers. There is reason to expect some unevenness in reaction to the self-service project, and particularly the supermarket, as the woman food shopper sought to meet self-expectations, and those of family, friends and society. This may have resulted in complex and varied shopping geographies. It is this we explore in the main part of the paper, analysing the reported opinions of those shopping in self-service grocery 
stores, and more particularly their opinions on shopping for fresh meat and greengrocery in such stores. Before this, we outline briefly the sources used in support of this study and provide an overview of the development of self-service and supermarket shopping and retailing in Britain.

\section{Data sources}

This research is underpinned by a reading of a series of contemporaneous major market research enquiries details of which are provided in Table One. Various national and local enquiries were undertaken into women's food shopping behaviours and attitudes during the period 1950 to 1970 . These reflected the needs of both manufacturers and retailers to understand the changing demands and motivations of generally increasingly affluent consumers, but also that some consumers had anxieties in coming to terms with the rapidly changing grocery retail industry. Such enquiries are of value in reconstructing and interpreting historical geographies of consumer reactions to retail formats.

Treating their statistical findings with due caution, it is possible to discern some broad trends emerging in relation to changing shopping habits. Unsurprisingly use has been made of these sources in previous studies of post-war retailing and consumption (for example Bowlby, 1984; Bowlby, 2000; Usherwood, 2000), although without the detailed focus employed here. Of the research reports used J. Walter Thompson's Shopping in Suburbia (1963) and the much smaller follow up enquiry The Changing Face of Supermarket Shopping (1964) relied quite heavily on qualitative methodologies and adopted a quasi-sociological approach (Bowlby, 2000). The others were more quantitative in nature, reporting on typically extensive data collection exercises probing various aspects of women shoppers' attitudes to the retail 
environment, including the self-service store and supermarket. For this study supplemental use is also made of the National Co-operative Archive, the archives of the grocery retailers Waitrose (part of the retailer the John Lewis Partnership) and $\mathbf{J}$ Sainsbury, and the archives of Mass-Observation, an organisation undertaking commercial market research during the 1950s. Use is also made of selected newspapers and trade magazines.

\section{--Insert Table One here -}

Findings of the study are also supported by reference to the magazines of local consumer groups joined to the National Federation of Consumer Groups (NFCG). By March 1967 there were 100 consumer groups, consisting of 18,000 consumers (Hilton, 2003). In this instance we draw upon opinion from local consumer group magazines relating to self-service shopping and supermarkets specifically in the period between 1961 and 1970, but such discussions can be set within broader anxieties relating to consumers' experiences of the retail and service industry in the period.

\section{Food shopping and retailing in Britain 1950-1970}

Although its beginning was marked by the continuation of certain austerity policies from the Second World War (Zweiniger-Bargielowska, 2000), the period 1950-1970 encompasses much of the long consumer boom enjoyed in post-war Britain which saw a remarkable growth in personal consumption (Benson, 1994). Consumer rationing was largely discontinued by 1955 . Between 1950 and 1973 GDP increased at an average annual rate of $3 \%$ and real disposable income per capita rose 
by about $30 \%$ in the 1950s and $22 \%$ in the 1960s (Obelkevich, 1994). The proportion of overall household expenditure on food fell from $33 \%$ of total household budget in $1953 / 4$ to $25.7 \%$ by 1970 (Obelkevich, 1994). Nonetheless, food still represented an extremely important category of household expenditure at the end of the study period. Furthermore, other areas of rapidly rising household expenditure, including on consumer durables, such as refrigerators, were connected either directly or indirectly with changing patterns of food purchasing and consumption. Rising household expenditure on the private car also influenced food shopping behaviours, with car registrations increasing from 5.5 million in 1960 to 13.5 million by 1973 (URPI, 1976). However, caution needs to be exercised against over-estimating the use of the car for shopping trips, especially in relation to the very numerous one-car households (Oakley, 1974; URPI, 1976; Bowlby, 2000). It was estimated that between 55\% and $65 \%$ of all shopping trips were made on foot in 1973 (Davies, 1973).

In relation to the retailing of food, early post-war Britain witnessed the increasingly rapid adoption of supermarket retailing. Contemporary trade definitions identified the supermarket as an outlet carrying all food groups plus basic household requisites, in other words providing “...everything the housewife will need to buy week to week for running the household...” (McClelland, 1962: 155). Much selfservice retailing and shopping also took place in smaller, often rapidly converted grocery outlets. These smaller formats stores were broadly defined as self-service stores in the contemporary literature, a term we adopt here. Not all of these selfservice stores sold fresh meat and greengrocery products. A useful definition of selfservice is provided in the trade journal Shop Review, 1955 (for details see du Gay, 2004). 
Acknowledging ambiguities in the format definitions employed by some contemporary sources, clear trends in the development of self-service retailing can be discerned. Whilst only 10 self-service stores could be identified in Britain in 1947 (Fulop, 1964), rapid growth of this retail innovation in the food trades resulted in an estimated 500 or so self-service stores by 1950 . Later estimates suggested that there were as many as 6,300 self-service stores in the UK by 1960 , and more than 28,000 in operation by the end of that decade (The Nielsen Researcher, 1963; 1970). Equally significant, an increasing amount of self-service retailing was taking place in larger supermarket formats (McClelland 1962: 155). In 1950 around 50 supermarkets were in existence, swelling in number to 572 by 1961 (McClelland, 1962; Birchall, 1994). By 1969 there were an estimated 3,400 supermarkets in Great Britain (The Nielsen

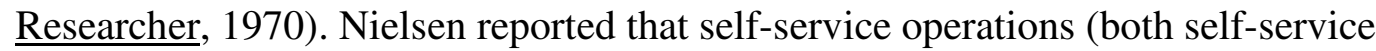
stores and supermarkets) accounted for $15 \%$ of grocery turnover in 1959 , rising to as much as $64 \%$ only ten years later (The Nielsen Researcher, 1970).

The particular significance of fresh meat and greengrocery departments to profitable supermarket operations was first revealed in analyses of the supermarket in the United States (Zimmerman, 1955; also British Productivity Council, 1953; OEEC, 1958a) and has been reflected upon in subsequent histories (for example Mayo, 1993). Average gross margins were higher in the meat and greengrocery departments than in grocery. More than $60 \%$ of meat departments and almost half of produce departments in American supermarkets were reported to operate on a fully self-service basis by the mid-1950s (Zimmerman, 1955; see also Teitelman, 1951). In Britain at this time selfservice food retailing in general was in comparative infancy (Shaw et al, 2004; Alexander, et al, 2005). Nonetheless operators of some leading self-service and supermarket chains understood the significance of extending and improving their 
offer in meat and greengrocery, both in terms of further reducing labour costs and potentially widening the appeal of self-service shopping. One supermarket operator considered that it would improve customer confidence in their ability to offer a wide range of goods (John Lewis Partnership Archive File 650/37). The Co-operative Union concluded that for the full benefits of self-service to be gained "the [Cooperative] Movement must develop comprehensive food self-service stores with meat and produce in the same selling area as groceries" (Co-operative Union, 1959: 1; Shaw and Alexander, 2007). The few available statistics from the period also suggest the potential of fresh food departments to deliver higher gross profits than other departments in the supermarket (MAF 208/56). Although the cost effectiveness of the switch to self-service in retailing fresh meat was subject to particular debate (for instance SA/PRO/612/10/1) many of the larger retailers turned toward at least some self-service mode of operation. Yet, as we discuss below, for such a switch to be successful it would require altering firmly-established perceptions and habits among shoppers.

\section{Opinions on self-service and supermarket shopping}

$\underline{\text { Shopping in self-service stores and supermarkets }}$

Findings of two of the largest and most detailed national surveys of women's food shopping attitudes and behaviours, Mrs Housewife and Her Grocer (Alfred Bird and Sons, 1958 (1st edition); 1961 ( $2^{\text {nd }}$ edition $)$ ) and Shopping in the Seventies (IPC, 1970) reveal a clear change in food shopping habits. While it was estimated that in 1957 only about one in ten housewives regular grocer was a self-service store (including supermarkets), by 1960 the figure was approximately one in four (Alfred Bird and Sons, 1961: 33). The IPC report of 1970 suggested that self-service shopping 
within the supermarket, defined rather loosely in the study as any large self-service grocery store, was the norm, with only approximately one in ten respondents reporting not shopping in such a store (IPC, 1970: 33). In broad geographical terms use of the supermarket was considered to be most common in London and the Home Counties and less so in Northern England, reflecting broad regional patterns of store development (Alfred Bird and Sons, 1961: 26; IPC, 1970: 33). Understanding of demographic variations in the use of self-service stores and the supermarket is incomplete, although by the early 1960s they were reported to be popular amongst those of lower-middle income and social class and by married women aged 25-44 (Alfred Bird and Sons, 1961: 17; Mass-Observation, 1963, TC/4/7/A).

Presenting women's reported attitudes to food shopping, the major surveys consistently found the ability to self-select goods, see everything available and save time as the most prevalent reasons for favouring self-service, and the absence of personal service among the most prevalent dislikes (BMRB, 1950; Alfred Bird and Sons, 1961; JWT, 1963; IPC 1970). Such views were also heard directly in the market research of Mass-Observation Ltd, which surveyed consumers on the issue of selfservice retailing on behalf of the grocery retailer International Stores. MassObservation's research notes from a survey of housewives in North West England in July 1956 include the following views of those who liked the self-service approach:

"Well, you can walk round and everything's out for you to see, everything out in front, and you're not waiting in a queue to be served, you can just pick what you want and get away." (Mass-Observation Archive: TC 78/3/B. Entry recorded as female, aged 39, working class). 
Another remarked:

“I think it's very good...for one thing you can see stuff displayed, and there's many a time you go to a shop and you forget a thing, don't you? But by going the self-service it's a reminder, isn't it?" (Mass-Observation Archive: TC 78/3/B. Entry recorded as female, aged 40, working class).

Those less inclined to self-service shopping frequently remarked on the impersonal nature of the shopping experience. One respondent stated for instance:

“Well, personally I don’t like self-service. They're too impersonal. People get to know you and what you want at the ordinary shops, and it's nice to have a little talk." (Mass-Observation Archive: TC 78/3/B. Entry recorded as female, aged 61, middle class).

And another remarked:

"Well, I think....well, some people like them..... Some do like them but I don't because I feel you just don't get that personal attention."(Mass-Observation Archive: TC 78/3/B. Entry recorded as female, aged 52, upper class).

Very similar likes and dislikes of self-service shopping were reported in J. Walter Thompson's in-depth study of opinions on supermarkets Shopping in Suburbia (JWT, 1963). The report emphasised the complexity of the modern shopping trip for consumers. It considered that new products, daily bargains, packaging and sales and 
display methods created a new and exciting shopping atmosphere, albeit one that could be confusing to some. It concluded: "All this makes shopping perhaps easier and more enjoyable, perhaps more wearisome and difficult. But certainly different." (italics in original: 15) and with the general impression that, in the case of supermarket shopping, psychological acceptance had not kept pace with the growth of the format.

Findings of these national surveys were, of course, reflective in many ways of the situation in the multitude of local shopping environments in which the woman food shopper might face the decision of whether to shop at markets, counter-service shops, self-service stores or the supermarket and in what combination. These dilemmas, and possible solutions to them, underpinned many commentaries on shopping for food in the publications of local consumer groups (for example Bristol Consumer, Vol. 1, N2, 1963; Service: the magazine of the Wolverhampton Consumer Group No. 3, 1969: 18; No 4, 1969: 18-20; Vigilant: the magazine of the Sutton and District Consumer Group, No 20, 1970: 3-8; No 21, 1970: 7-10; Consuming Interest: journal of the Southampton and District Consumer Group, No 10, 1971: 5-6).

\section{$\underline{\text { Selective adoption: Buying fresh meat and greengrocery self-service }}$}

The assertion of Shopping in Suburbia that the psychological acceptance of the supermarket was lagging behind the physical growth of the format seemed particularly relevant in connection with the purchase of fresh meat and greengrocery. Early advocates of self-service retailing in Britain quickly acknowledged the difficulties in relation to the sale of pre-packaged fresh meat and greengrocery. One review cautioned that whilst evidence from the United States revealed that virtually any food product could be sold self-service, a policy of slow transformation to self- 
service was desirable in relation to the sale of fresh produce in Britain. Methods of retailing fresh fruit and vegetables and meat by self-service were considered relatively crude, leaving much to be desired in the standards of display (Hammond, 1949; see also British Productivity Council, 1953; OEEC, 1956).

The next two decades witnessed considerable efforts being made in the prepackaging for sale of fruit and vegetables and fresh meat, and some not inconsiderable progress (see for example, Merchandising Vision, 1964a; also Merchandising Vision, 1955). For the partisan editorial of British Cellophane Limited's house magazine the pre-packaging of vegetables represented an "astonishing aspect of the marketing revolution that is now in full swing in Britain." (Merchandising Vision, 1958). Yet even it was forced to conclude that fresh meat was still often regarded as one of the problem children of the supermarket, being highly perishable, messy and difficult to present attractively (Merchandising Vision, 1964b). The Organisation for European Economic Co-operation (1960) noted that European self-service retailers had not made as much progress with the sale of fresh meat either in comparison with their handling of grocery lines, or with the situation in the United States where, the report considered, industry was more geared to the needs of self-service.

Whilst important supply chain improvements were necessary, and these continued to be made throughout the study period, retailers still faced an apparent disinclination among many shoppers to purchase pre-packaged fruit and vegetables, and especially fresh meat, from supermarkets. As a result a number of firms retained counter-service in the meat departments of some of their supermarkets. This disinclination was revealed both in national surveys of consumer behaviour, such as Shopping in Suburbia (JWT, 1963) and Shopping in the Seventies (IPC, 1970) (see also EIU, 1961; Lintas, 1968; Merchandising Vision 1966), and in surveys undertaken 
by local consumer groups (see for instance Vigilant, February 1970, No 20). IPC's Shopping in the Seventies in particular made clear the extent of the selective adoption problem for self-service and supermarket retailers; concluding that the growth of supermarket shopping was not mirrored by that of 'one-stop shopping'. The report noted that housewives who used a supermarket on their main shopping trip were more inclined to purchase fruit and vegetables and fresh meat at another shop (during that same shopping trip) than at the supermarket. In the case of the purchase of fresh meat the ratio of those using a butcher rather than the supermarket was reported to be almost two to one (IPC, 1970).

Estimates of the market share of self-service stores and supermarkets in the fresh food categories differ between surveys, but the data from a series of major enquiries highlight the issue of selective adoption by consumers during the study period (EIU, 1961; JWT, 1963; Merchandising Vision, 1966; Lintas, 1968; IPC, 1970). According to one survey from the end of our study period, the counter-service butcher continued to be the strongly preferred place for the purchase of meat, with three quarters of those interviewed reported as still using a butcher's shop regularly (IPC, 1970). Freshness was considered the major attraction of shopping for meat at the butcher's shop, closely followed by being able to personally select the cut of meat wanted. Personal service was reported as the third ranked perceived advantage of the traditional counter-service butcher (IPC, 1970). The consequences of such attitudes for the self-service store and supermarket selling meat were clear. The IPC report estimated that supermarkets and self-service stores accounted for as little as $25 \%$ of all fresh meat purchases by the end of the study period (IPC, 1970; see also Lintas, 1968). 
Similarly, in the purchasing of fresh fruit and vegetables the traditional greengrocer's market stall or shop was reported to have perceived advantages for the consumer in terms of selling fresher products, giving better value and being more pleasant (EIU, 1961; IPC, 1970). Data from the IPC (1970) survey of shopping habits suggested that the perception that greengrocers' goods were fresher was pre-eminent in consumers' choice of outlet for such purchases. Supermarkets and large self-service stores were estimated to account for about $25 \%$ of all fresh vegetables sales and $35 \%$ of all fresh fruit sales by 1970 (IPC, 1970).

Again contemporary survey work allows us to hear the voice of the consumer. For instance, presenting observations on a shopping trip in Barry, South Wales, the author of an account published by Cardiff and District Consumer Group stressed the expert service and knowledge of the independent butcher, among others, and provided an implicit comparison with the rather more harrying, unsatisfying experience of supermarket shopping in the town (Cardiff Consumer, December, 1965, 3-4). Both Mass-Observation's survey for International Stores and J Walter Thompson's Shopping in Suburbia probed attitudes on purchasing pre-packaged perishable products in self-service outlets, the problem being such that the later included a dedicated survey on the issue which was completed by 120 female respondents. One sceptical interviewee said of self-service to Mass-Observation:

"Well, to be quite honest with you, I'm not at all keen on them. Well, you see in the Co-op yesterday - they have one here the Co-op do - the cheese was all wrapped up in that transparent paper and it looked alright, but it wasn't fresh when it was unwrapped. I prefer to see it cut before my eyes, and potatoes and vegetables - I like 
to choose them and see them weighed. I don't like them in these bags." (MassObservation Archive: TC 78/3/B. Entry recorded as female, aged 55, working class)

Similar views were reported by a range of respondents in J Walter Thompson's study: 'I'm not so keen on some wrapped things. I wouldn't buy potatoes or greens because although they have air holes they sweat and smell musty....With perishable items like meat you have to use your discretion. Meat and bacon is quite good in cellophane. It is not handled by fingers." (JWT, 1963: 29)

"I'm always a little suspicious about them all. You don't know how long they have been packed. Pre-packed frozen foods are good. They are kept in a deep freeze. But I bought cauliflower once and its turned black and brown when cooked. I've always bought fresh since then.” (JWT, 1963: 29)

'I like to see what I am buying. I have bought cheese but it doesn't last long. It's quite mouldy the next day. I've bought tomatoes and found them quite soft when I get home. It's too risky to buy things like that. You don't know how long they have been packed.' (JWT, 1963: 29)

In summary, there was an apparent distrust over the purchase of pre-packaged fresh meat and fruit and vegetable products by self-service methods among some women food shoppers. Such products were considered as possibly not fresh and likely to spoil quickly, they were sometimes perceived as less flavoursome, and some reported buying in predetermined quantities irksome (J. Walter Thompson, 1963; Mass-Observation Archive, TC 78/3/B). 


\section{Explaining selective adoption: the theory and practice of women's food shopping}

The concept of perceived risk provides some explanation for the pattern of selective adoption identified, and hence adds support to the notion of a gap between the growth of self-service and supermarket retailing and its psychological acceptance by shoppers. As we have shown, for some women food shoppers perceived risk was considered too high when deciding whether or not to purchase fresh meat and greengrocery products in the self-service grocery store and supermarket. Importantly, although concerns were frequently expressed in terms of product quality issues, they also reflected attendant social and psychological risks (Mitchell, 1999; Cases, 2002). The origin and significance of these social and psychological risks have been explained in an earlier section of the paper by reference to theorisation on the act of shopping (particularly Miller, 1998; Miller et al, 1998).

Data from several contemporaneous research studies confirm that during our study period housewives commonly perceived shopping for the family's food to be a challenging task requiring skill, although not the greatest chore of housekeeping (IPC, 1970; Oakley, 1974; Scott, 1976; Sofer, 1965). For instance, almost three quarters of the 500 housewives surveyed by IPC (1970) considered shopping to be an aspect of their role involving skill (IPC, 1970, Table 35; Table 26). Clearly, skilled homemaking increasingly meant skilled purchasing, especially for working women with families (Bowlby, 1984). As Table Two illustrates, when asked the task they felt it most important to do well, 'preparing meals' and 'shopping for food' headed the list, considerably ahead of other responsibilities. Similarly more than $85 \%$ of those questioned reported that they felt proficiency in shopping to be a distinguishing feature between 'good housewives' and 'bad housewives' (IPC, 1970; see also Joyce, 
1967). These data reflect respondents' perceptions of the significance of food shopping in terms of social and psychological risk.

\section{-- Insert Table Two here --}

It would appear that many housewives felt their proficiency most tested when shopping for fresh meat. An investigation into the meat buying habits and knowledge of its members by the Finchley and Hendon Consumer Group, for instance, noted that whilst most were selective, knowledgeable and careful they knew little about different cuts of meat (Quest: Journal of the Finchley and Hendon Consumer Group, No 22, 1969, 11; see also Scott, 1976). The IPC survey of 1970 concluded that in the case of the butcher personal service was highly important because:

“...this is the product where housewives are least sure of their own judgement. Some housewives indeed leave their meat purchase entirely in their butcher's hands: 'He knows what I like.'” (IPC, 1970: 43)

For the author of J. Walter Thompson's report Shopping in Suburbia (1963) the supermarket's scale and modus operandi could also tell against it; raising perceptions of a less knowledgeable, rather indiscriminate bulk-buying operation, offering less choice and limited information on fresh produce (JWT, 1963). Indeed, the subtitle to the follow-up report The Changing Face of Supermarket Shopping (JWT, 1964) asked the question "Are supermarkets making the progress they expected in gaining the affection of the housewife?" Shoppers were being asked to buy on trust (JWT, 1963). Without adequate reassurance, this was unlikely to succeed 
given the perceived significance of carrying out food shopping and meal preparation. The conclusion of Shopping in Suburbia was stark:

"...the supermarket cannot always be a novelty, and when it is no longer an exception to the rule, wider choice and extra convenience may have less weight. To offset this possibility, one school of supermarket thinking looks to a more personalized future when advice will be easily available to the customer. (This should tone down the isolation complex and help with the 'learning' process.)...Meanwhile supermarkets have a psychological role to fulfil. The public is not quite convinced that power and good intentions go hand in hand; and when there are more and larger supermarkets there may be a distinct need for reassurance on this point." (JWT, 1963: 36, parenthesis in original)

If British self-service store and supermarket retailers were seeking to emulate their US counterparts in presenting “...a public image of systematic efficiency without human labor and its problems" (Mayo, 1993: 178) then this generated new challenges to convince the women food shopper of their suitability as the choice for an entire food shopping trip. It would seem, based upon the data of women's shopping practices and their views about these that we have been able to uncover, that until these challenges were met the geographies of women food shoppers remained more varied than might otherwise be expected (Gregson et al, 2002). The changing postwar retail environment, of course, reflected the increasing economies of scale and scope in food retailing achieved by the larger grocery multiples with their self-service stores and supermarket operations. Indeed, their advantage over smaller shops contributed to the failure to realise planning ambitions surrounding standards of 
access and choice (Bowlby, 1984: 183). Yet we can also clearly witness the impression of women food shoppers' household dynamics on their varied engagement with the changing environment in much the way that Jackson et al. (2006) suggest.

\section{Educating women food shoppers}

Attempting to fulfil the responsibilities for proficient shopping in new selfservice retail environments could create anxiety. It required shoppers to nurture different skills than those employed in the traditional counter-service environment where, in principle at least, fresh goods could be viewed unpackaged, more choice could be made over size and selection, and most importantly the retailer was on hand to provide information and advice. Shopping in the self-service environment necessitated greater self-reliance, product knowledge and consumer literacy (see Usherwood, 2000). As we have discussed, this was particularly the case in relation to shopping for produce and, unsurprisingly, it became a focus for attempts to inform and educate the consumer.

Self-service and supermarket shopping were among the topics covered as part of the wider movement toward consumer education. For example, The British Broadcasting Corporation's regular and popular Woman's Hour radio programme discussed the rise of self-service stores and the supermarket, contextualised in related discussions on cookery recipes and other household tasks. Similarly, written publications of consumer organizations were used to both represent and educate the consumer. In the 1950s, the Consumer Advisory Council became involved in a multitude of surveys and reports. Articles in Shopper's Guide taught the consumer to judge for herself as part of an agenda of creating the ideal consumer as a precursor to an ideal market (Hilton, 2003: 190). As well as publishing their regular journal 
Which?, in 1963 the Government-funded Consumers' Association appointed a fulltime Education Officer to institute educational schemes in schools and colleges.

Retailers, farmers' representatives and packaging firms all sought to increase consumer awareness and literacy toward the self-service shopping for meat and fruit and vegetables through advertising and educational initiatives. The work of the Produce Prepackaging Development Association (PPDA), a trade association formed in 1954 comprising of producers, manufacturers, suppliers and retailers, was important in this regard. The association planned a particularly concerted publicity scheme between 1957 and 1959 using newspapers, trade journals, radio and television to educate food shoppers of the merits of buying fresh foods pre-packaged and to promote self-service retailing (see MAF 208/45-49; MAF 208/117; Produce Prepackaging, Vol.7, No.12, 26-7). The campaigns of retailers also highlighted the benefits of buying fresh produce at the self-service store and supermarket. The opening of the new Waitrose supermarket in Streatham, London, for instance, saw the retailer plan an advertisement campaign in the local press that stressed the modern nature of the shopping experience offered. Under headlines such as "Shopping brought up-to-date" (Streatham News, $16^{\text {th }}$ December, 1955) and "Meat buying the modern way" (Streatham News, $18^{\text {th }}$ November, 1955), the reader was to be informed that a Waitrose supermarket was the modern shop for the modern woman, and one in which she could help herself to the pick of fine quality cuts of meat, quickly, conveniently, without fuss. Similarly, in its newspaper for housewives, Hinton's, a regional grocer, stressed the equality offered by the self-service retailing of prepackaged fresh meat by reference to a customer's story: 
"Another customer I talked to ...had this to say about the new idea. 'I think this prepacked meat is a wonderful idea. You can select a piece to suit your purse, and I have to choose very carefully because my husband is ill and we are only getting sick pay at the moment. At the butcher's it's a bit embarrassing to tell him that you can't afford the piece he has cut for you and you often come away with something which costs more than you can really afford. Here you just choose one the price you want to pay. And its good meat, too."' (Tees-side Housewife, Vol 1 N1, 1956)

Many retailers used additional means to promote understanding of the supermarket and the produce they sold. "Housewife evenings" were held in which would-be shoppers were shown around a new store prior to its opening, and visiting days arranged for school children tasked with improving their knowledge of home economics (The Gazette of the John Lewis Partnership, Vol. XLV, No25, July $20^{\text {th }}$ 1963: 602). Customer magazines were also used to inform the shopper about the fresh produce in the store, whether a self-service store or otherwise (see for example Family. Sainsbury's Magazine for Every Woman. Autumn 1961, p53; Summer, 1962, pp38-9; Autumn, 1962, p50-52; Winter 1962, pamphlet insert Sainsbury's Book of Beef Cookery). Some self-service retailers trialled customer advisers, employed to provide shoppers with information on recipes, cuts of meats, methods of preparation and the like (see for example Self-Service Times and Modern Marketing No.25, January 1959 p4; No.45, October 1960 p4). In his survey of women's attitudes to shopping, Sofer (1965) found only equivocal support for such a service, although he reflected that some respondents might have been disinclined to voice support considering it tantamount to an expression of one's own inadequacy in this fundamental task (p205). 
At one level then, attempts were being made to educate women food shoppers about shopping for fresh food items at the self-service store and the supermarket with a view to reducing the perceived risk of self-service shopping. Here, there are very strong parallels here with Dowling's study of shopping at Woodward's department store in post-war Vancouver in which she concludes that the food floor was not only the site where women bought their families foods, it was also where they were taught to be modern (Dowling, 1993: 314).

\section{Conclusions}

The development of self-service stores and particularly the supermarket represented significant innovations in the post-war British retail environment. Store numbers grew rapidly and they accounted for an increasingly large share of grocery market sales. However, we would argue that there is significant danger in adopting a simple modernization thesis in explaining the growth of even obviously successful formats such as the supermarket. Such a thesis views them as necessarily superior to the existing retail operations. It is certainly true that self-service stores and supermarkets increasingly became the norm for the food shopping public. As we have noted, in 1957 only about one in ten housewives' regular grocer was a self-service outlet; by 1970 it was about seven in ten (Alfred Bird and Sons, 1961; IPC, 1970). However, our analysis of the available data on the shopping attitudes and behaviours of housewives presents clear evidence of selective adoption in relation to the purchase of fresh meat and greengrocery products, with new self-service stores and supermarkets frequently bypassed in favour of more traditional retail outlets when it came to shopping for these goods. Large self-service stores and supermarkets might have portrayed themselves as a 'one-stop shopping' solution but this was very often 
not the case. Selective adoption by shoppers, centred around product category, was very clearly in evidence.

De Grazia's (2005) study of the emergence of supermarket retailing in postwar Italy reveals some similarities with regard to consumer reaction; shoppers inexperience contributing to restricted engagement with the supermarket's growing range of merchandise, anxieties over the cost of flawed supermarket shopping and appeals from shoppers for more advice from the retailer to assist them in coming to terms with the self-service environment (de Grazia, 2005: 410; see also Spiekermann, 2006). Many of the reasons we offer for selective adoption in Britain are revealed to be relevant there too. Yet the widespread introduction of self-service methods and supermarket retailing in Italy occurred much later than it Britain (OEEC, 1960). A European Productivity Agency sponsored report $(\mathrm{OEECb}, 1958)$ reported survey data from early 1956 showing that only $6 \%$ of more than 2300 Italian consumers surveyed knew how self-service shops operated and that as few as $2 \%$ had been in such a shop. What is notable from our research is the evidence of the persistence of selective adoption in Britain long after the diffusion of the self-service store and supermarket and despite some significant supply-chain improvements.

Explanation for British women food shoppers' varying reactions toward selfservice stores and the supermarket, and their resultant geographies of shopping, has been contextualised in debates over the nature and meanings of shopping and linked to the role and responsibilities of the housewife in the post-war household. The emergence of new self-service formats could generate interest and even excitement, but the changes in the structure and operations of retailing they represented also brought challenges and anxieties, especially where shopping was considered imbued with risk. As we have shown, contemporary surveys reveal the centrality of food 
provisioning among housewives' principal tasks, and the maintenance of expectations placed upon women to perform this role proficiently meant that perceived risk related to format switching could be greater than we might otherwise presume, particularly for fresh food shopping. The perceived risk was typically articulated in our survey data in terms of the physical risk of product failure, but we consider that social and psychological risks were attendant as a result of the expectations placed on women to meet their families' food shopping needs. Here we clearly see further evidence of the social embeddedness of shopping practices and their rootedness in the household context (Jackson et al., 2006: 61). The available data suggest that one result was the emergence of some new and diverse shopping geographies with choice between stores for food shopping driven by a complex mix of factors.

Obviously aware of the importance of fresh food departments to the economic logic of the large self-service store and the supermarket, retailers sought to alter perceptions of their fresh food offer and hence reduce shoppers' perceived risk through a number of strategies. New supply chain management initiatives for fresh food lines were clearly fundamental to improving product quality, especially with regard to fresh meat (Mayo, 1993; EIU, 1964; MAF, 303/69; MAF 303/71). Additionally, retailers and others sought to change housewives' perceptions of the fresh food offer through promotional and educational campaigns. Media campaigns, store magazines and even dedicated customer advisors were all employed during the study period to promote the fresh meat and greengrocery departments of self-service stores and supermarkets. Retailers sought to reassure women food shoppers that being at the vanguard of modern shopping was consistent with their roles and responsibilities for the care of the household. 
Our identification of persistent selective adoption of self-service retailing innovations and conceptualisation of this as resulting from the socially embedded nature of shopping along with the related perceived risk of housewives in undertaking household tasks reveals directions for future work. First, we need to understand more fully how family make-up, neighbourhood cultures and class structures impacted upon the selective adoption we have identified (de Grazia, 2005). Existing data sources are insufficiently robust for this task and more research work needs to be undertaken. Whilst we have reported the social classes of respondents to MassObservation surveys used in this paper for completeness, we have not identified any verifiable trends here from across our time period. A new AHRC funded research project to gather oral histories of early supermarket shoppers should provide useful material in this regard ${ }^{2}$. Second, the relationship between the development trajectory of retail innovations such as the self-service store and supermarket and consumers' reactions to them warrants more detailed examination. The tendency of many historical studies to provide the blanket label of 'self-service' to the various store formats trialled and developed in this period underestimates the diversity of shopping experiences offered to consumers by retailers seeking to maximise the opportunities of self-service trading. Unpicking such diversity will allow for a more nuanced account of the changing practices of food retailing and consumption in post-war Britain.

\footnotetext{
${ }^{2}$ Shaw G. and Alexander A. 'Reconstructing Consumer Landscapes: Shopper reaction to the supermarket in early post-war England.' For details see www.sobe.ex.ac.uk/shopping
} 


\section{Acknowledgements}

The authors would like to acknowledge the generous support of the Leverhulme Trust in funding the research for this paper as part of the project 'The coming of the supermarket: geographies of a retail innovation in Britain c.1945-c.1970.' We would also like to acknowledge the Trustees of the Mass-Observation archive, University of Sussex and the archivists at J Sainsbury, the National Co-operative Archive and the John Lewis Partnership in making available the archive material used. Thanks are extended to the three anonymous referees for their useful comments on this paper and to Professors Michelle Lowe and Arieh Goldman for their helpful suggestions. The usual disclaimers apply. 


\section{References}

Alexander A, Shaw G and Curth L, 2005, "Promoting retail innovation: knowledge flows during the emergence of self-service and supermarket retailing in Britain" Environment and Planning A 37 805-821

Alfred Bird and Sons Ltd., 1958, Mrs Housewife and Her Grocer [first edition] (Alfred Bird and Sons, London)

Alfred Bird and Sons Ltd., 1961, Mrs Housewife and Her Grocer [second edition] (Alfred Bird and Sons, London)

Anon., 1961, "Debate on the B.B.C. Woman's Hour about prepackaged fresh food" Produce Prepackaging 7 (12) 26-7

Beharrell B, Denison T J, 1995, "Involvement in a routine food shopping context" British Food Journal 97 (4) 24-29

Benson J, 1994, The Rise of Consumer Society in Britain 1880-1980 (Longman, London)

Birchall J, 1994, Co-op. The People's Business (Manchester University Press, Manchester)

Bowlby S R, 1984, "Planning for women to shop in Postwar Britain" Environment and Planning D: Society and Space 2 179-199

Bowlby S, 1994, "From corner shop to hypermarket: women and food retailing", in Women in Cities. Gender and the Urban Environment Eds J Little et al. (MacMillan Education Limited, Basingstoke) pp61-83

Bowlby R, 2000, Carried Away. The Invention of Modern Shopping (Faber and Faber, London) 
The British Market Research Bureau Ltd. (BMRB), 1950, Self- Service in Great Britain. A Study of the Latest Method of Grocery Retailing (BMRB, London)

British Productivity Council (Anglo-American Council on Productivity), 1953, Fruit and Vegetable Storage and Pre-packaging (BPC: London)

Campbell C, 1998, "Consumption and the rhetorics of need and want" Journal of Design History $11235-246$

Cases A-S, 2002, "Perceived risk and risk-reduction strategies in Internet shopping" The International Review of Retail, Distribution and Consumer Research 12 (4) 37594

Clarke I, Hallsworth A, Jackson P, de Kervenoael A, Perez de Aguila R and Kirkup M, 2006, "Retail restructuring and consumer choice 1: long-term local changes in consumer behaviour: Portsmouth, 1980 - 2002” Environment and Planning A 38 2546

Co-operative Union, 1959, Report on Self-Service Trading (Co-operative Union, Manchester)

Davies R L, 1973, “Patterns and profiles of consumer behaviour" Occasional Paper Research Series No 10, Department of Geography, University of Newcastle upon Tyne

De Grazia V., 2005, Irresistible Empire. America's Advance through $20^{\text {th }}$-Century Europe’ (Belknap Harvard, London)

Dowling R, 1993, "Femininity, place and commodities: a retail case study" Antipode 25 295-319

du Gay P, 2004, "Self-service: retail, shopping and personhood" Consumption, Markets and Culture 7 149-163 
The Economic Intelligence Unit (EIU), 1961, Self-Service Retail Business Survey series (EIU Limited, London)

The Economic Intelligence Unit (EIU), 1964, Butchers and Greengrocers Retail Business Survey series (EIU Limited, London)

Fox B J, 1990, "Selling the mechanized household: 70 years of ads in Ladies Home Journal" Gender \& Society 4 25-40

Fulop C, 1964, Competition for Consumers: A Study of the Changing Channels of Distribution (Andre Deutsch, London)

Giles, J, 2005, “Good housekeeping: professionalizing the housewife, 1920-1950” in Women and Work Culture Eds Cowan, K and Jackson, L.A. (Ashgate, Aldershot) pp70-86

Goldman A, 1982, "Adoption of supermarket shopping in a developing country: the selective adoption phenomenon" European Journal of Marketing 16 17-26

Goldman A, 2001, "The transfer of retail formats into developing economies: the example of China" Journal of Retailing 77 221-242

Goldman A, Ramaswami S, Krider R E, 2002, "Barriers to the advancement of modern food retail formats: theory and measurement" Journal of Retailing 78 281295

Gregson N, Crewe L, Brooks K, 2002, "Shopping, space, and practice” Environment and Planning D: Society and Space 20 597-617

Hammond A E, 1949, Self-Service Retailing (Lockwood Press, London)

Hilton M, 2003, Consumerism in $20^{\text {th }}$-Century Britain. The Search for a Historical Movement (Cambridge University Press, Cambridge) 
Humphery K, 1998, Shelf Life. Supermarkets and the Changing Cultures of Consumption (Cambridge University Press, Cambridge)

International Publishing Company (IPC), Women's Weekly Group, 1970, Shopping in the Seventies. Highlights of a Survey of Housewives (IPC, London)

Jackson P, 1999, "Consumption and identity: the cultural politics of shopping" European Planning Studies 7 25-39

Jackson P, Perez de Aguila R, Clarke I, Hallsworth A, de Kervenoael R, Kirkup M, 2006, "Retail restructuring and consumer choice 2 : understanding consumer choice at the household level" Environment and Planning A 38 47-67

J Walter Thompson, 1963, Shopping in Suburbia. A Report on Housewives' Reactions to Supermarket Shopping (J Walter Thompson Company Limited, London)

J Walter Thompson, 1964, The Changing Face of Supermarket Shopping. Are Supermarkets Making the Progress they Expected in Gaining the Affection of the Housewife? (J Walter Thompson Company Limited, London)

Joyce, T, 1967, The New Housewife (British Market Research Bureau Limited, London)

Lewis J, 1992, Women in Britain since 1945 (Blackwell, Oxford)

Lintas, 1968, Food, Women and Shops, Volume 2 (Lintas Special Projects, London)

Lury C, 1996, Consumer Culture (Polity Press, London)

McClelland W G, 1962, "Economics of the supermarket” The Economic Journal March 154-170

Mayo J M, 1993, The American Grocery Store. The Business Evolution of an Architectural Space (Greenwood Press, Connecticut) 
Merchandising Vision 1955, 'Greengrocery goes glamorous', Volume 1, No.1, pages 3-6; 1958, 'Food Facts', Volume 4, No. 2 p2; 1964a 'Growing the veg, to suit the pack' Volume 9, No. 1, pages 12-14; 1964b ‘Supermarket Selling Strategy Shown', Volume 9, No. 5, p11; 1966 'Self-service meat' Volume 11, No. 1, pages 3-11

Miller D, 1995, "Consumption as the vanguard of history", in Acknowledging Consumption. A Review of New Studies Ed D Miller (Routledge, London)

Miller D, 1998, A Theory of Shopping (Polity Press, Cambridge)

Miller D, Jackson P, Thrift N, Holbrook B, Rowlands M, 1998, Shopping, Place and Identity (Routledge, London)

Mitchell V-W, 1999, "Consumer perceived risk: conceptualisations and models" European Journal of Marketing 33 (1/2) 163-195

Mitchell V-W, McGoldrick P J, 1996, “Consumers' risk-reduction strategies: a review and synthesis" The International Review of Retail, Distribution and Consumer Research 6 1-33

Morris L, 1990, The Workings of the Household: A US-UK Comparison (Polity Press, Cambridge)

Oakley A, 1974, The Sociology of Housework (Martin Robertson and Co. Ltd., London)

Obelkevich J, 1994, “Consumption”, in Understanding Post-War British Society Eds Obelkevich, J. and Catterall, P. (Routledge, London)

Organisation for European Economic Co-operation (OEEC), 1958a, Marketing and Distribution of Meat and Dairy Products in the United States (OEEC, Paris) 
Organisation for European Economic Co-operation (OEEC), 1958b, The Consumer's Food Buying Habits (OEEC, Paris)

Organisation for European Economic Co-operation (OEEC), 1960, The Economic Performance of Self-Service in Europe (OEEC, Paris)

Phillips S, Alexander A, Shaw G, 2005, "Consumer misbehavior: the rise of selfservice grocery retailing and shoplifting in the United Kingdom c.1950-1970" Journal of Macromarketing 25 66-75

Scott R, 1976, The Female Consumer (Associated Business Press, London)

Self-Service Times and Modern Marketing No. 25 January 1959 page 4; No. 45 October 1960 page 4

Shaw G and Alexander, A (forthcoming 2007) 'British co-operative societies as retail innovators: interpreting the early stages of the self-service revolution', Business History

Shaw G, Curth L, Alexander A, 2004, "Selling self-service and the supermarket: the Americanisation of food retailing in Britain, 1945-1970" Business History 46 568-582

Sofer C, 1965, "Buying and selling: a study in the sociology of distribution" Sociological Review 13 183-209

Spiekermann U, 2006, 'From neighbour to consumer: the transformation of retailerconsumer relationships in twentieth-century Germany' in The Making of the Consumer. Knowledge, Power and Identity in the Modern World Ed F Trentmann (Berg: Oxford) pp147-174

Strasser S, 1982, Never Done: A History of American Housework (Pantheon, New York)

Tees-side Housewife, 1956, "Self-service saves time" Vol. 1 (N1), December, Page 1 
Teitelman S, 1951, "Self-service meat retailing in 1950” Journal of Marketing 15 $307-318$

The Nielsen Researcher, 1963, "Annual review: the changing pattern of grocery trading”, March-April (Nielsen Marketing Service, Oxford)

The Nielsen Researcher, 1970, "Future trends in packaged goods", SeptemberOctober (Nielsen Marketing Service, Oxford)

The Unit for Retail Planning Information (URPI), 1976, Hypermarkets and Superstores: Report of a House of Commons Seminar (report U1) (URPI, Reading)

Thompson C, 1996, "Caring consumers: gendered consumption meanings and the juggling lifestyle" Journal of Consumer Research 22 388-407

Usherwood B, 2000, “Mrs Housewife and Her Grocer': the advent of self-service food shopping in Britain", in All the World and her Husband Eds M Andrews, M Talbot (Cassell, London) pp113-130

Woodruffe-Burton H, Eccles S, Elliott, R, 2002, "Towards a theory of shopping: a holistic framework" Journal of Consumer Behaviour 1 256-266

Zimmerman M M, 1955, The Super Market. A Revolution in Distribution (McGraw Hill Book Company Inc., New York)

Zukin S, 2004, Point of Purchase. How Shopping Changed American Culture (Routledge, New York)

Zweiniger-Bargielowska I, 2000, Austerity in Britain: Rationing, Controls and Consumption 1939-1955 (Oxford University Press, Oxford)

Magazines of local consumer groups: 
Bristol Consumer. The Magazine of the Bristol Consumer Group, "A survey of supermarket shopping in Bristol" 1 (2)

Cardiff Consumer. The Magazine of the Cardiff and District Consumer Group, December 1965, pages 3-4

Consuming Interest. The Magazine of Southampton and District Consumer Group, 1971, "Some ways of saving money when shopping at the supermarket" 10, pages 5-6

Quest. Journal of the Finchley and Hendon Consumer Group, 1969, 22, page 11

Service. The Magazine of the Wolverhampton Consumer Group, February 1969, “Sainsbury's has it!", 3, page 35

Service. The Magazine of the Wolverhampton Consumer Group, June 1969, "Why I don't shop at Sainsbury's"”, 4, page 3

Vigilant. The Magazine of the Sutton Consumer Group, 1970, "Sainsbury's in Sutton", 20, pages 15-18.

Vigilant. The Magazine of the Sutton Consumer Group, 1970, "Sainsbury's in Sutton", 21, 7-9.

Records of government ministries:

MAF 208/117 (Ministry of Agriculture and Food) The Produce Prepackaging Development Association Limited: history and areas of interest for MAF 1962-1965. The Public Record Office, London

MAF 208/45 (Ministry of Agriculture and Food) The Produce Prepackaging Development Association Limited. Reports by Marketing Officers, Minutes of Council Meetings 1954-1955. The Public Record Office, London 
MAF 208/48 (Ministry of Agriculture and Food) The Produce Prepackaging Development Association Limited. Reports by Marketing Officers, Minutes of Council Meetings 1957-58. The Public Record Office, London

MAF 208/49 (Ministry of Agriculture and Food) The Produce Prepackaging Development Association Limited. Reports by Marketing Officers, Minutes of Council Meetings 1958-60. The Public Record Office, London

MAF 208/56 (Ministry of Agriculture and Food) Sale of Fruit and Vegetables in SelfService Stores and Supermarkets, 1963. The Public Record Office, London

MAF 303/69 (Ministry of Agriculture and Food) Redevelopment of Major Markets 1964-1968: Comments submitted by National Federation of Fruit and Potato Trades Ltd. and the Supermarket Association of Great Britain. The Public Record Office, London

MAF 303/71 (Ministry of Agriculture and Food) Improvement of Wholesale Horticultural Markets by Supermarket Growth: Comments by the Supermarket Association of Great Britain, 1963. The Public Record Office, London

Other archive sources:

Family: Sainsbury's Magazine for Every Woman. Autumn 1961, page 53; Summer, 1962, pages 38-9; Autumn, 1962, pages 50-52; Winter 1962, pamphlet insert Sainsbury's Book of Beef Cookery. J Sainsbury Archive (file SA/FC/FAM/1)

J Sainsbury 1962, Evidence to the Committee of Equiry into Fatstock and Carcase Meat Marketing and Distribution. J Sainsbury Archive (file SA/PRO/6/2/10A)

“Waitrose Supermarket Development 1955-8” Memo 11602, 03.11 .1958 from

Chairman to Managing Director. John Lewis Partnership Archive (file 650/37) 
The Gazette of the John Lewis Partnership, 1963, XLV, 25, 20 July, page 602. John Lewis Partnership Archive

'International Tea Company Survey, 1956,' Mass-Observation Archive Topic

Collection (TC) 78/3/B, Commodities, 1941-1964, (Mass-Observation Archive,

University of Sussex)

'The off-side of the counter: Proposed book, 1963' Mass-Observation Archive Topic

Collection (TC) 4/7/A, Shopping 1939-1963' (Mass-Observation Archive, University of Sussex) 
Table One. Selected market research enquiries concerned with shopping in selfservice and supermarket outlets.

\begin{tabular}{|c|c|c|}
\hline Report Name & Publisher and date & $\begin{array}{l}\text { Summary sample } \\
\text { information* }\end{array}$ \\
\hline $\begin{array}{l}\text { Questions and Answers on } \\
\text { Co-operative Self-Service }\end{array}$ & CWS, Manchester, 1949 & $\begin{array}{l}\text { Random sample of } \\
\text { shoppers in four different } \\
\text { co-operative self-service } \\
\text { stores }\end{array}$ \\
\hline $\begin{array}{l}\text { Self Service in Great } \\
\text { Britain }\end{array}$ & $\begin{array}{l}\text { The British Market } \\
\text { Research Bureau Ltd., } \\
\text { London. } 1950\end{array}$ & $\begin{array}{l}200 \text { consumers } \\
\text { interviewed }\end{array}$ \\
\hline $\begin{array}{l}\text { Mrs Housewife and Her } \\
\text { Grocer (1st edition) }\end{array}$ & $\begin{array}{l}\text { Alfred Bird and Sons Ltd. } \\
1958\end{array}$ & $\begin{array}{l}3000 \text { housewives } \\
\text { interviewed }\end{array}$ \\
\hline $\begin{array}{l}\text { Mrs Housewife and Her } \\
\text { Grocer (2nd edition) }\end{array}$ & $\begin{array}{l}\text { Alfred Bird and Sons Ltd. } \\
1961\end{array}$ & $\begin{array}{l}4000 \text { housewives } \\
\text { interviewed comprising: } \\
2000 \text { doorstep interviews } \\
\text { and } 2000 \text { interviews at the } \\
\text { grocery shop ( } 238 \text { grocery } \\
\text { shop locations used) }\end{array}$ \\
\hline Shopping in Suburbia & $\begin{array}{l}\text { J. Walter Thompson } \\
\text { Company Ltd., London. } \\
1963\end{array}$ & $\begin{array}{l}\text { Interviews in selected } \\
\text { areas, each area accounting } \\
\text { for } 100 \text { short interviews } \\
\text { with housewives in the } \\
\text { supermarket street, } 200 \\
\text { lengthier interviews of } \\
\text { housewives in shopping } \\
\text { centre catchment areas. } 20 \\
\text { additional interviews to } \\
\text { investigate attitudes to the } \\
\text { supermarket 'in more } \\
\text { detail' and without formal } \\
\text { questionnaires }\end{array}$ \\
\hline $\begin{array}{l}\text { The Changing Face of } \\
\text { Supermarket Shopping }\end{array}$ & $\begin{array}{l}\text { J. Walter Thompson } \\
\text { Company Ltd., London. } \\
1964\end{array}$ & $\begin{array}{l}210 \text { surveys undertaken in } \\
\text { seven London boroughs }\end{array}$ \\
\hline Shopping in the Seventies & $\begin{array}{l}\text { IPC, Women's Weekly } \\
\text { Group, London. } 1970\end{array}$ & 513 housewives surveyed \\
\hline
\end{tabular}

* Information on sampling derived from the relevant publication 
Table Two. Housewives' perception of the significance of tasks in their role.

\begin{tabular}{|l|c|}
\hline Task identified & $\begin{array}{l}\text { Percentage of housewives considering } \\
\text { it most important task for a housewife } \\
\text { to do well. }\end{array}$ \\
\hline Preparing meals & \multicolumn{1}{|c|}{28} \\
\hline Shopping for food & 15 \\
\hline Keeping yourself looking good & 12 \\
\hline Cleaning and dusting & 7 \\
\hline Washing clothes & 3 \\
\hline Mending clothes & 2 \\
\hline Washing-up & 2 \\
\hline Shopping for clothes & 2 \\
\hline Making beds & \\
\hline
\end{tabular}

Source: IPC (1970), Table 25 